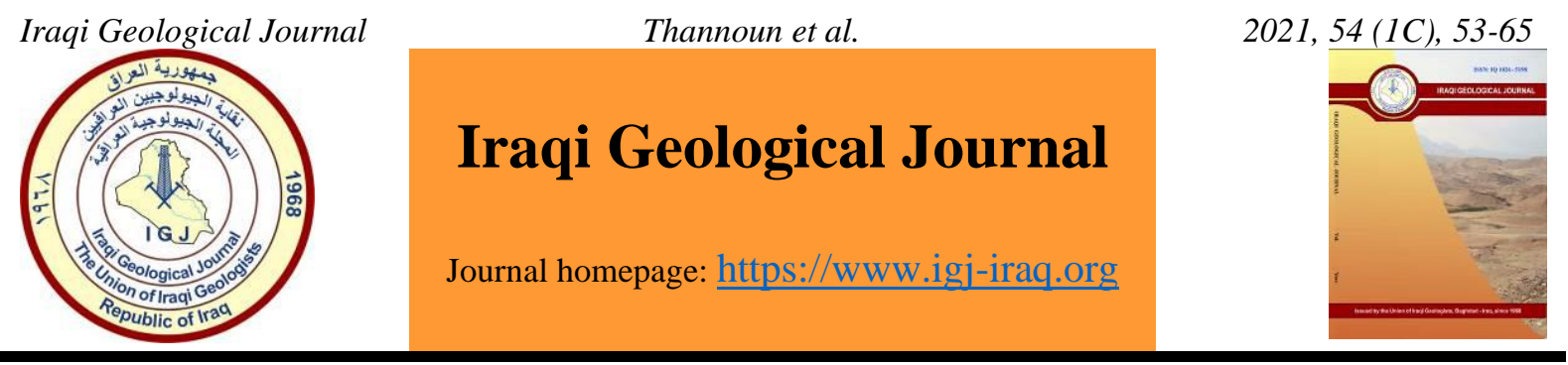

\title{
Three Dimensional Terrain Modeling for Tectonic Geomorphology of Chinara Anticline, Northern Iraq
}

\author{
Rayan Gh. Thannoun ${ }^{1}$, Azealdeen S. Al-Jawadi ${ }^{2}$ " and Hadeer Gh.M. Adeeb ${ }^{2}$ \\ ${ }^{1}$ Remote Sensing Center, Mosul University, Mosul, Iraq \\ ${ }^{2}$ Dams and Water Resources Research Center, Mosul University, Mosul, Iraq \\ *Correspondence: azealdeenaljawadi@uomosul.edu.iq
}

Received: 27 November 2020; Accepted:19 January 2021; Published : 31 March 2021

\begin{abstract}
Analysis of the terrain using three-dimensional models offers a deep insight view of ground surface topography and terrain representation. The Chinara anticline is one of the main structures of NW-SE trends for the highly folded zone in northeastern Iraq. The objective of this study is to understand the interrelationship between topography and morphotectonic features using three-dimensional models. This research employed fourth generates principal raster derivative products from the DEM using ArcGIS. To understand the undulating of this anticline with the morphotectonic style, the adaptive equation has been suggested to determine the direction and amount of the main tectonic forces, which can be applied to other undulated anticlines. The values of northeastern and southwestern limbs undulating index UI are 11.7 and 7.8 respectively that indicates the strong tectonic force towards the northeast. Two listric faults have been conducted via the field survey that confirmed by remotely sensed interpretation and DEM products. These listric faults had an intensive impact in comparison with concluded strike-slip faults, and then the Chinara anticline would be less structural undulating in a region of vicinity syncline to Perat undulation. The morphotectonic landscapes reveal that the listric fault has branched into two parts, the first one extending to form the anticline and the other comprises the structural dilemma.
\end{abstract}

Keywords: 3D terrain modeling; Morphotectonic; Undulating index; Listric faults; Chinara anticline

\section{Introduction}

Remote sensing and digital elevation model has been extensively used in geomorphological and geological studied and updating the tectonic setting for many regions on the world as well as, Also, these techniques are used in the study of drainage basins and their geological and geomorphological implications (Al-Sulttani and Beg 2020) and (Fatah, et al., 2020). The area under investigation is located in the NE part of Iraq within Erbil Governorate, Mergasor District, and bounded geographically between latitude ( $36^{\circ} 52^{\prime} 0^{\prime \prime} \mathrm{N}$ and $36^{\circ} 41^{\prime} 0$ " $\mathrm{N}$ ) and longitude $\left(43^{\circ} 45^{\prime} 30^{\prime \prime} \mathrm{E}\right.$ and $\left.44^{\circ} 13^{\prime} 0^{\prime \prime} \mathrm{E}\right)$. The Chinara anticline surrounds several neighboring towns, including Charbut, Harene, Dirakapra, Shaffte, Darbotic, Alka, Shanidar, and Bekhme from northwest to southeast (Fig. 1). The anticline has many features such as a sinuous and undulated axis, different drainage networks, broad wings, and some blind valleys. The southeastern part of the northeastern limb has a dense straight linear drainage pattern. Through Alka Village, the anticline is widening to the northwestern plunge in comparison to the other parts. The northwestern part of the northeastern limb of the anticline is recognized by a broad flexible drainage pattern. The effect of the tectonic and structural processes will possibly pass on different densities of

DOI: $\underline{10.46717 / i g j .54 .1 C .5 M s-2021-03-25}$ 
dendritic drainage patterns in the same fold and semi-identical rock hardness. The region undergoes intense earthquakes of varying magnitudes due to the pressure built up between the colliding of the Arabian plate with the Eurasian plate (Jackson, et al., 1981; Hessami and Jamali, 2006; Onur, et al., 2017).

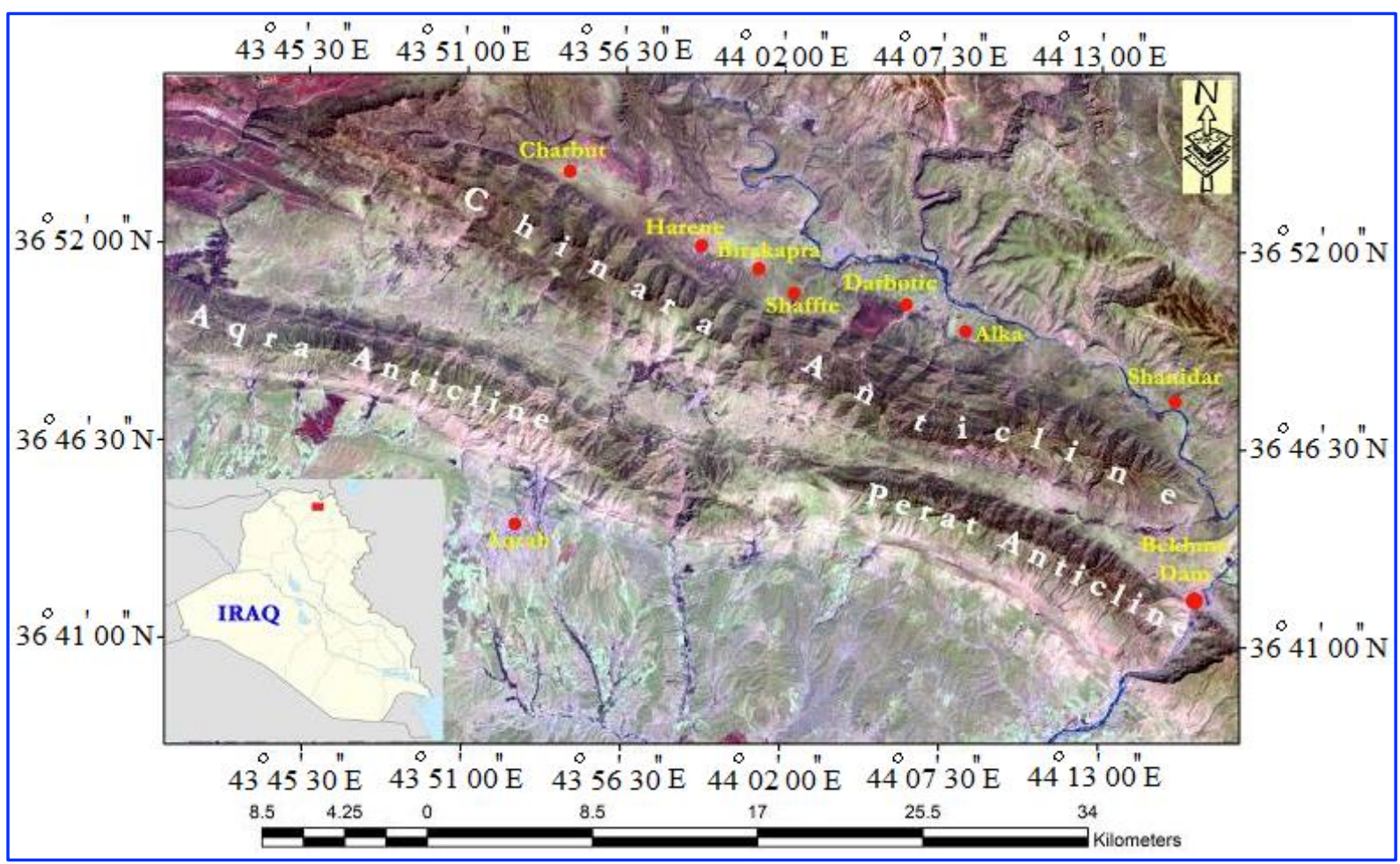

Fig. 1. The satellite image of the study area shows the location of the Chinara anticline

Due to rock hardness differences and high folding, the region is exposed to different weathering grades, badlands, and topographical conditions, which create densely dendritic drainage patterns (Sissakian, 2013). The study area has no extensive geological surveys because it is situated in a tectonic activity region and characterized by a rugged topography within the range of the unstable zone, most outcrops in it are difficult to reach (Jassim and Goff, 2006). The principal objective of the current study is to set 3D terrain modeling for the anticline to explain the morphotectonic features and the geological, tectonic, and structural explanations for the perception of ambiguity coincidence. For civil protection purposes, this interpretation may be useful in geologic hazards in towns and villages along the anticline, such as rockslides, rock falls, and karstification concerning earthquakes.

\section{Geological Setting}

The Chinara anticline is a double plunging asymmetrically anticline trend towards northwestsoutheast and extends approximately $50 \mathrm{~km}$ (Fig. 2) (Sissakian, et al. 1997; Al-Hamdani, 1991). It is bordered on the southwest by the anticlines of Aqrah and Perat, and along the northwest by the northwestern plunge of Bradost anticline. The exposed formations are briefly mentioned here from the Lower Jurassic to the Quaternary deposits (Fig. 2). The anticline carapace is the Qamchuqa Formation (Lower Cretaceous) Sissakian (2013), and the other formations represent the remaining parts of the anticline. Tectonically, during the rotation of the Arabian plate anticlockwise to the northeast direction, the area has been affected by the Arabian plate indenture; located in the front of this part of the Arabian Plate, which deforms the region of the study area. According to previous studies, Numan (1997); Numan 
(2000), the Bitlis thrust zone of Iraq as a structural manifestation is characterized by the ramming of the indenture into the overriding Turkish plate.

\section{Materials and Methods}

Landsat images and DEM interpretation are useful in the assignment of lithology, lineaments, dips, and inclinations which support linear and areal interpretations through different computer packages. The abnormal linear and areal parameters were controlled by geology, structure, and lithology (Anand et al. 2017). Fig. 3 provides a general flowchart of the methods used in this research. This paragraph explains all the procedures for the development of the Chinara anticline surface model in 3D surface analysis.
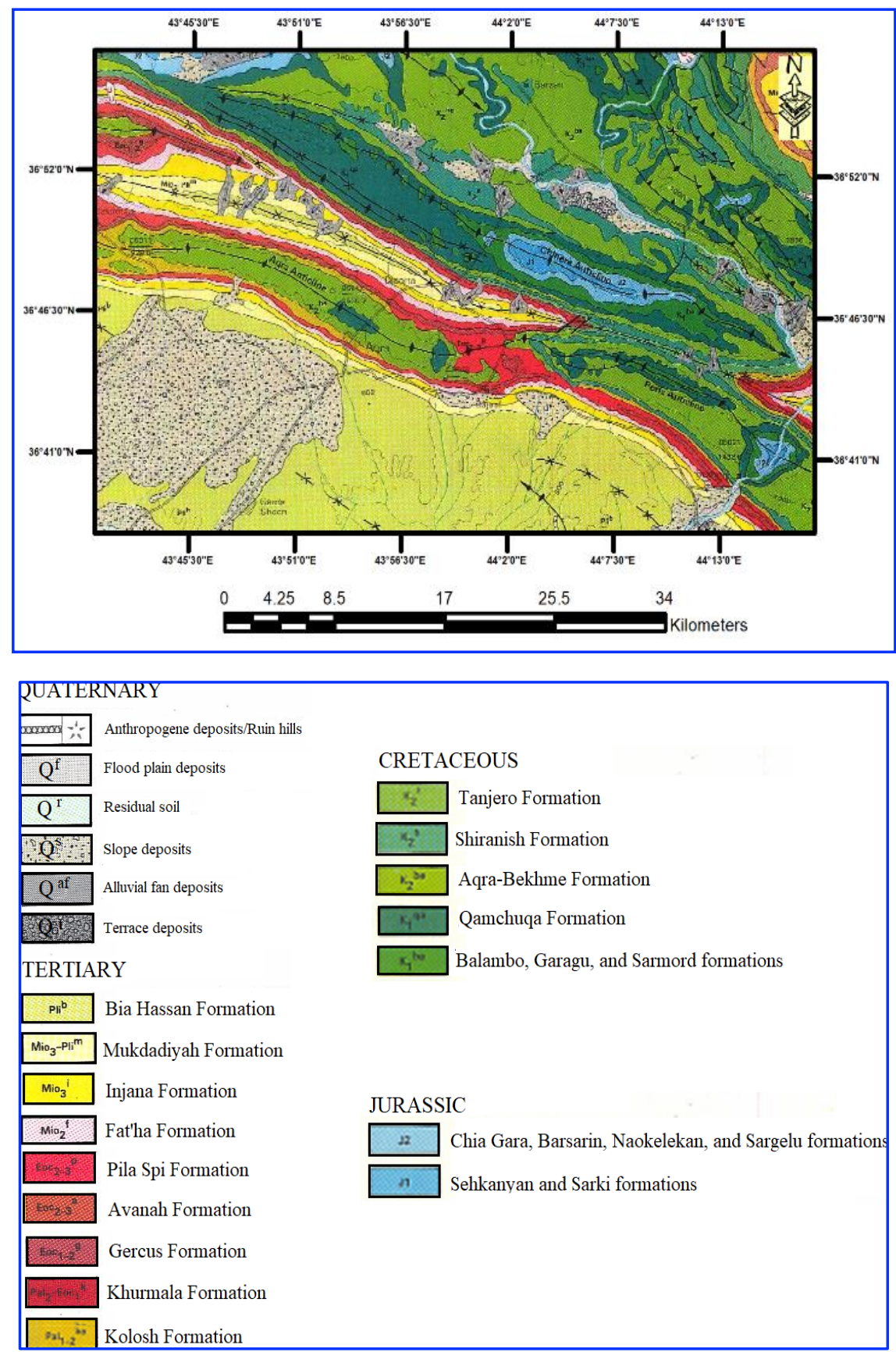

Fig. 2. Geological map of the Chinara anticline after (Sissakian, et al., 1997) 


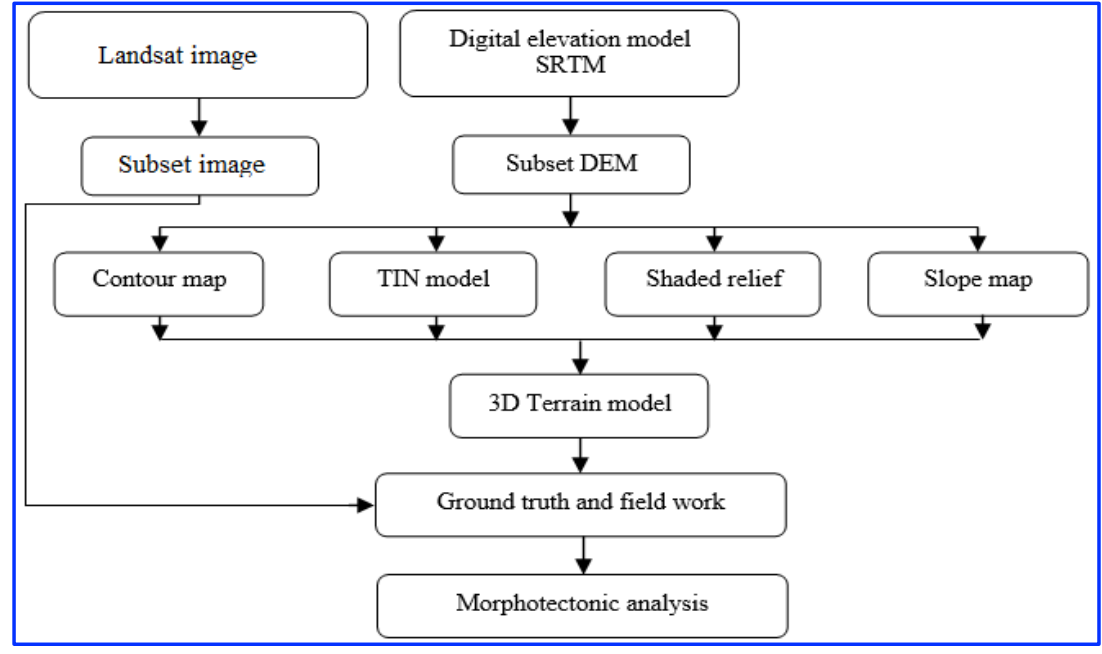

Fig. 3. General flowchart of the study

The materials used primarily are the 2001 Endevour satellite images - derived elevation data known as Digital Elevation Model (DEM) $(30 \mathrm{~m})$ resolution. The DEM is used to apply the topographical analysis of the Chinara anticline and to design a 3D model for the extraction of morphotectonic features in the study area. The ArcGIS utilizing a spatial analyzer surface to obtain automated thematic maps of DEM products for instance of contours, TIN, hillshade, and slope maps. When corrected from sink and spark effects the digital elevation model covered Chinara anticline was used. DEM's thematic map is defined as follows:

\subsection{Contour Map}

The contour representation is an extraordinary visual approximation of the surface of the earth since it gives a detailed reasonable amount at a minimum graphical load (Robinson, 1971). In combination with accessible ArcGIS tools and methods of data collection, the production techniques of the contour have substantially changed (Kettunen, et al., 2017). Recently, DEM-contour mapping has mapped contour vector lines with swift automatic extraction, high position efficiency, and detail level which cannot be carried out by manual drawing. Elevations of the area are detected, ranging from less than 500 meters to over 1700 meters (a.s.1.), as shown in the contour map (Fig. 4).

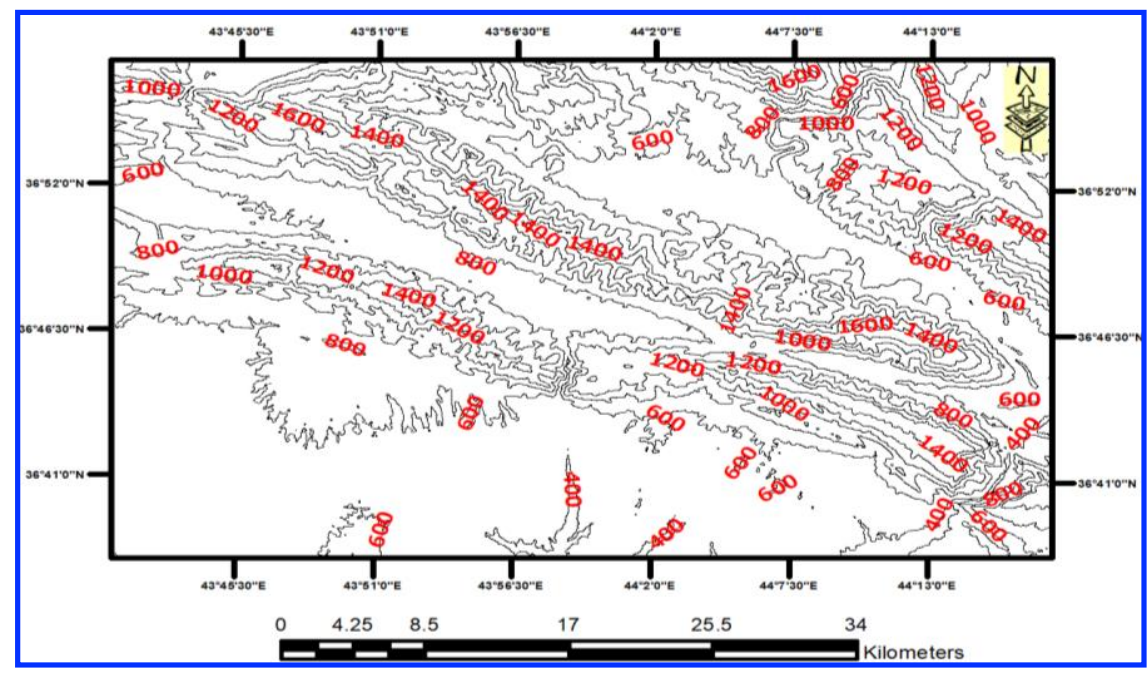

Fig. 4. Contour map of the study area 


\subsection{Triangulated Irregular Network}

The Triangular Irregular Network (TIN) is an interpolation method used for approximating unknown values of linear and nonlinear structures (Ripley, 2005; Mitas and Helena, 1999). TIN also represents a form of spatial network vector of interconnected triangles, through the triangulation of a group of vertices (points) (Fig. 5), nine elevation zones have been defined and the maximum elevation of the Chinara anticline located towards northwestern and southeastern plunges have values of about 1710 and $1610 \mathrm{~m}$ respectively. The map demonstrates relief features as well as topographical elements. In the specific zones in northwestern and southeastern plunges, the maximal uplift of the anticline was determined and this reflects an important tectonic factor of the fold which is explained later.

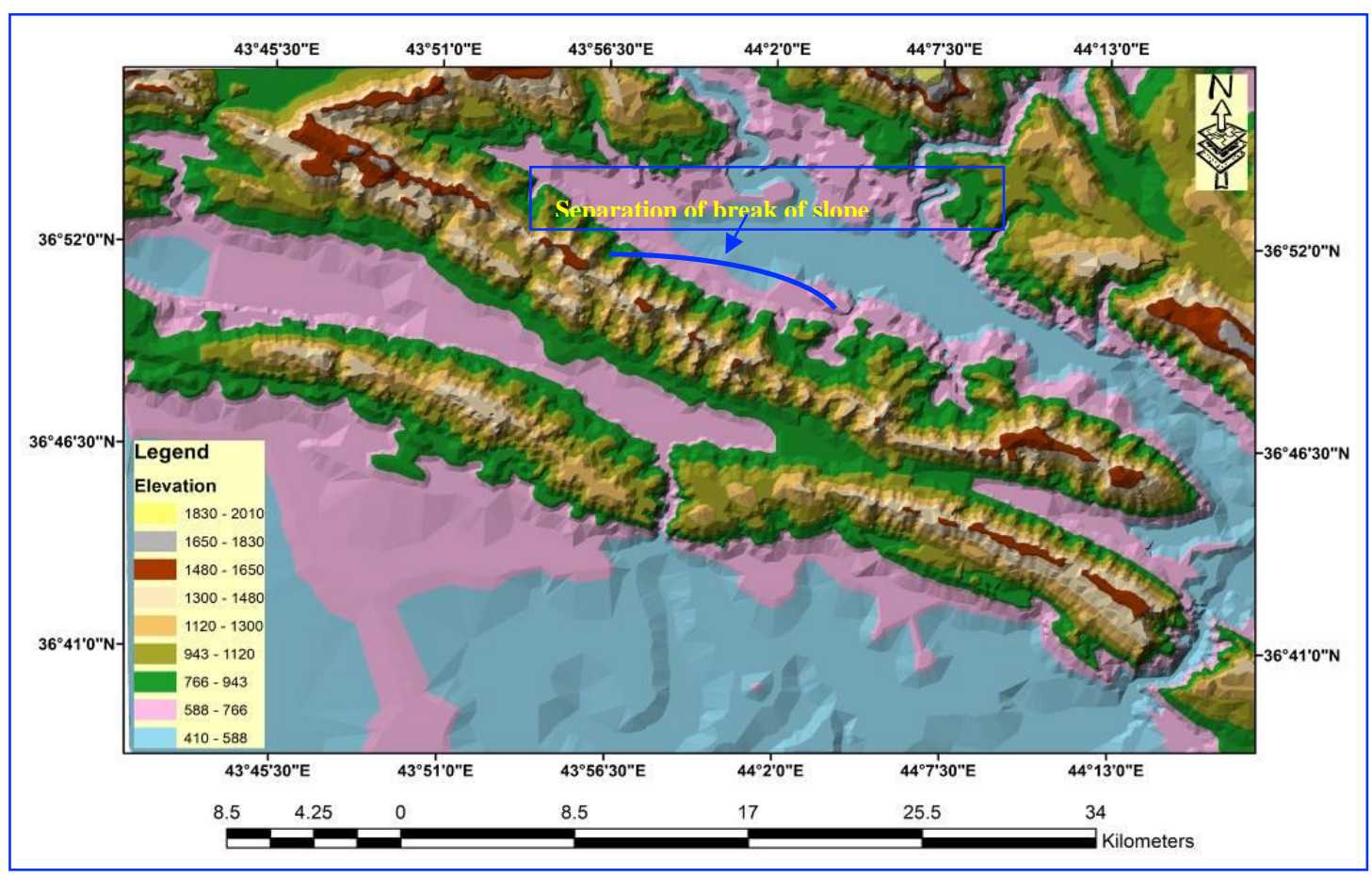

Fig. 5. Shows TIN map of the study area

\subsection{Shaded Relief Maps}

The terrain hillshade is a function dependent on the aspect, slope, and equivalent to the elevation difference raster (Mukul et al., 2017). The output shaded relief images were grey shades of the digital number between 0 and 255 (black and white). Shaded relief images can be comparable with the radar images showing bare ground without vegetation as well as the relations between geology and topography (Konon and Śmigielski, 2006; Szypula, 2017; Thornton et al., 2018). Shaded relief maps are created generally by the use of a selected lighting effect based on elevation variations. In this context, the value to change both the vertical angle (elevation) and the horizontal angle (azimuth) of the sun is calculated to determine the shade of each image. A set of shaded-relief images of the Chinara anticline was created for these different elevations and different azimuths of the light source. The best way to revealing detailed faulting, major and minor lineaments, tectonic setting, topographical relief, and general deformation patterns of the anticline is to display shaded relief images (Fig. 6). All shaded relief images confirm the structural relations between the Chinara anticline and the surrounding exposed structures (Fig. 6A). Besides, the sudden breaks of the outcrops in the central area of the anticline and the undulated style of the fold (Fig. 6B). 

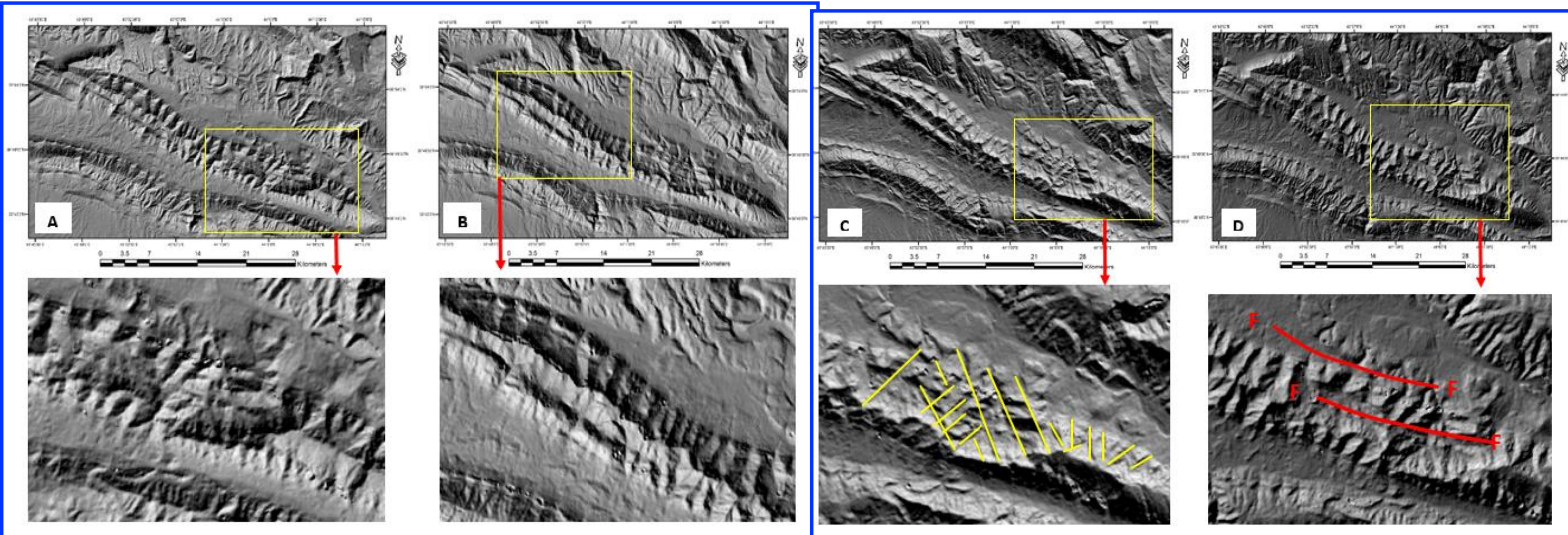

Fig. 6. Shaded relief maps; A: azimuth 140, elevation 30; B: azimuth 240, elevation 30; C: azimuth 20, elevation 25 and D: azimuth 315 , elevation 20

\subsection{Slope Map}

The slope is a measure of elevation changing rate over a horizontal distance (Choanji, 2016). It is an essential parameter of multiple applications such as morphotectonic, geomorphology, etc. and it is used to depict land relief. Slope maps are documented for decades however the creation of these maps was limited until the development of GIS software and other modern techniques. The slope map was prepared in this study based on the DEM. The slope level of the Chinara anticline is quite varied and ranging from gently sloping to very steep (Van Zuidam, 1979). The slope was divided into nine levels (Fig. 7), and the maximum slope is about $68.2^{\circ}$ and it corresponds to the maximum elevation in the area. According to Van Zuidam's classification (Van Zuidam, 1979), the maximum slope of the study area falls in the very steep category and the lowest slope falls in the flat or gentle slope. The presence of high values slope is associated with concluded fault locations. Furthermore, the slope showed clear curvature and undulating in all parts of the anticline and determined its structural framework.

\subsection{D Terrain Landscape Model}

The 3D terrain model is a method for representing the landscape digitally. The 3D model can also be used for representing subsurface formations and their associated features (Thornton, et al. 2018). Landsat false-color compound satellite image with bands (R:7, G:4, B:2) was draped over the DEM to create the 3D view image of Chinara anticline to show the undulating axis and morphotectonic features (Fig. 8). 3D terrain features provide the possibility to see from different directions and with a range of exaggerations all of the topographical environment, structural framing, and geological domain of the entire anticline. Based on the 3D image, the deducted faults parallel to the anticline axis appeared to affect the highly weathered zone in the middle of the anticline. The structural process controls to drainage pattern and leads to form two huge catchment areas in the location of the branched 58istric fault (Fig. 9).

\subsection{Fieldwork}

To clarify the ambiguous features along the anticline, the Landsat image, dated 17-18 Oct. 2018 was used to show the field path. The field reconnaissance and detailed survey were carried out in the field for the period from 15 to 18 Oct. 2018. The reconnaissance survey took place on and around the anticline. The detailed survey involves the valleys of ambiguous features in the vicinity of Darbotic Village close to the core of the anticline (Fig. 10). 


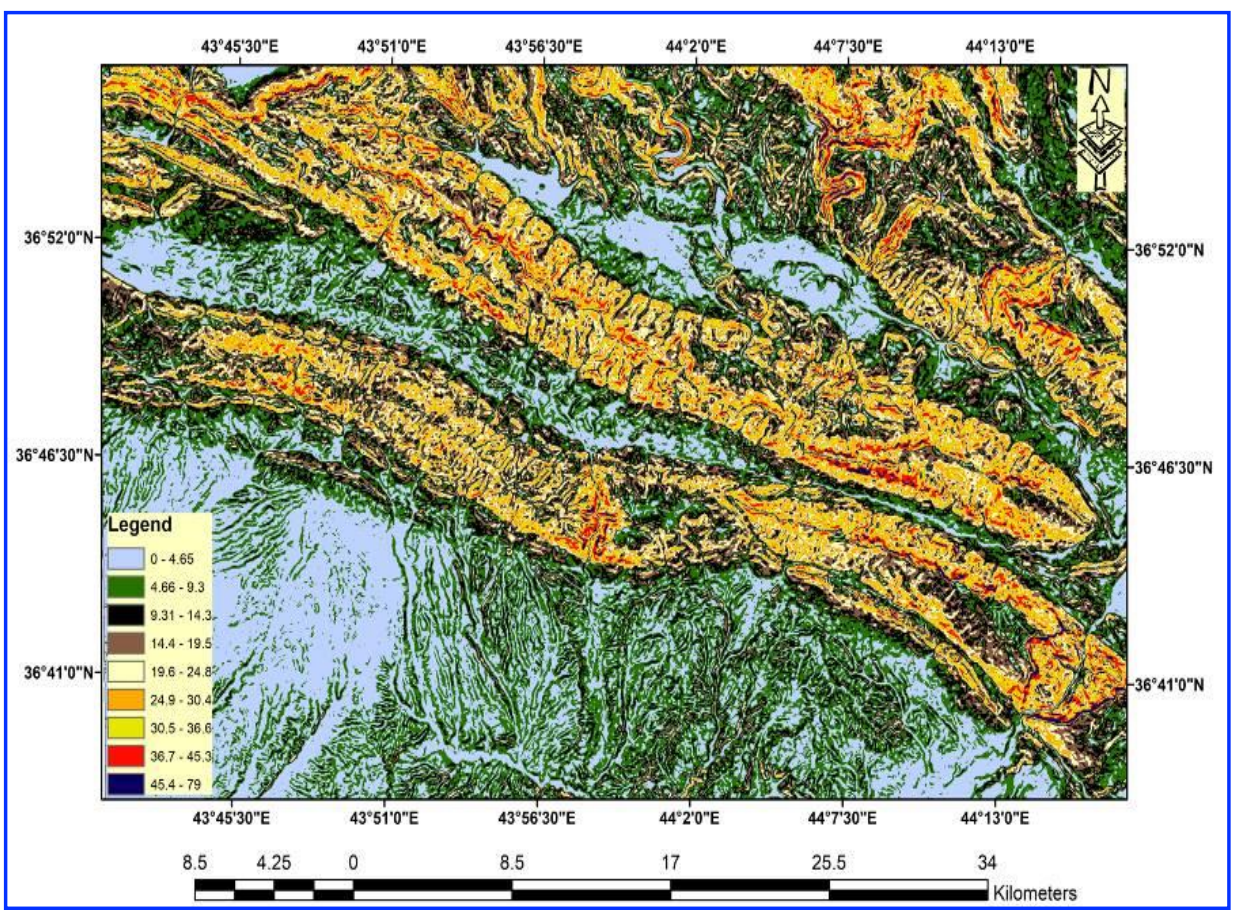

Fig. 7. Slope map of the study area

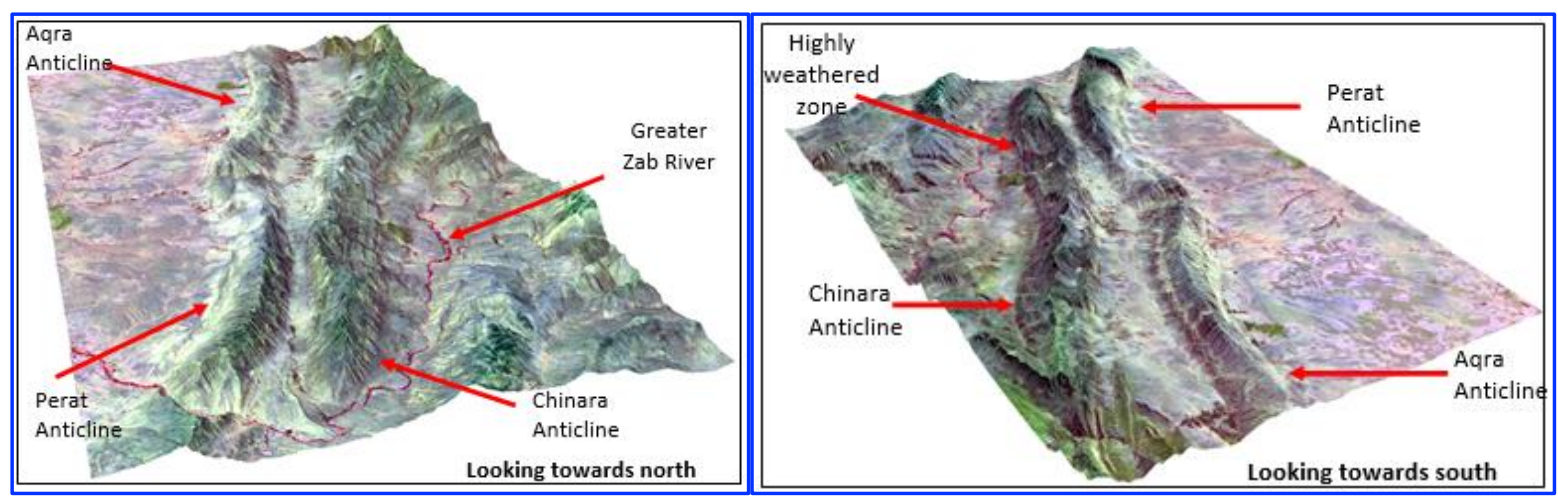

Fig. 8. 3D panoramic terrain images show the undulating axis and morphotectonic features
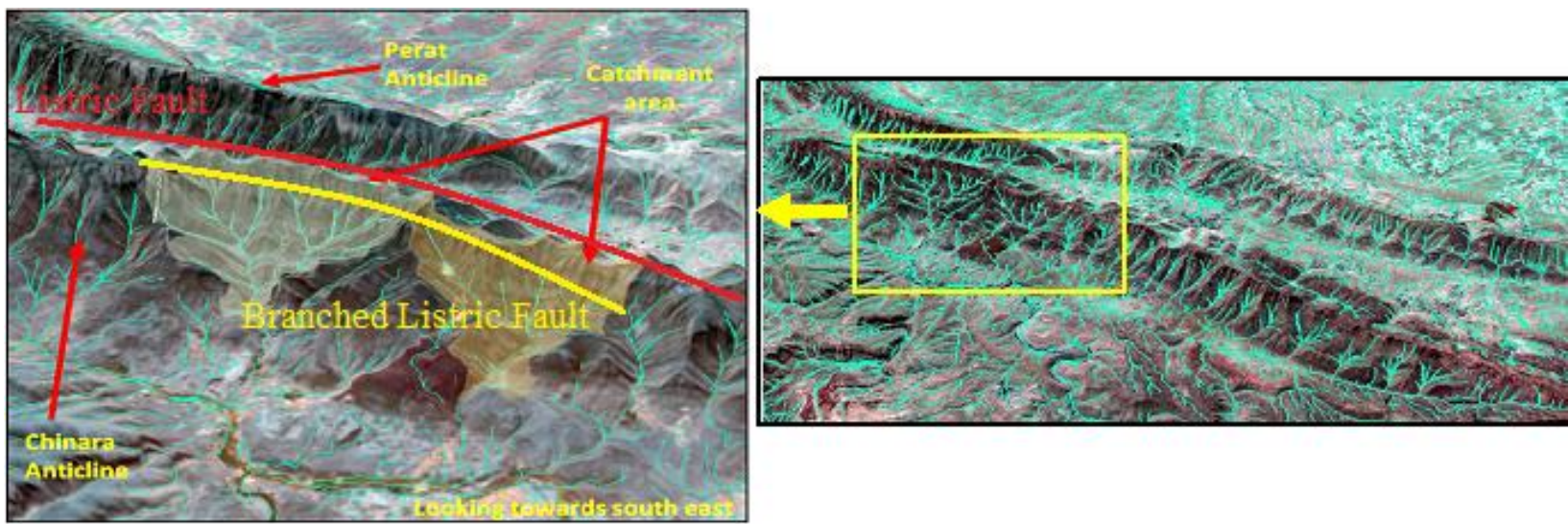

Fig. 9. 3D model shows the two huge catchment areas at the NE limb of Chinara anticline 


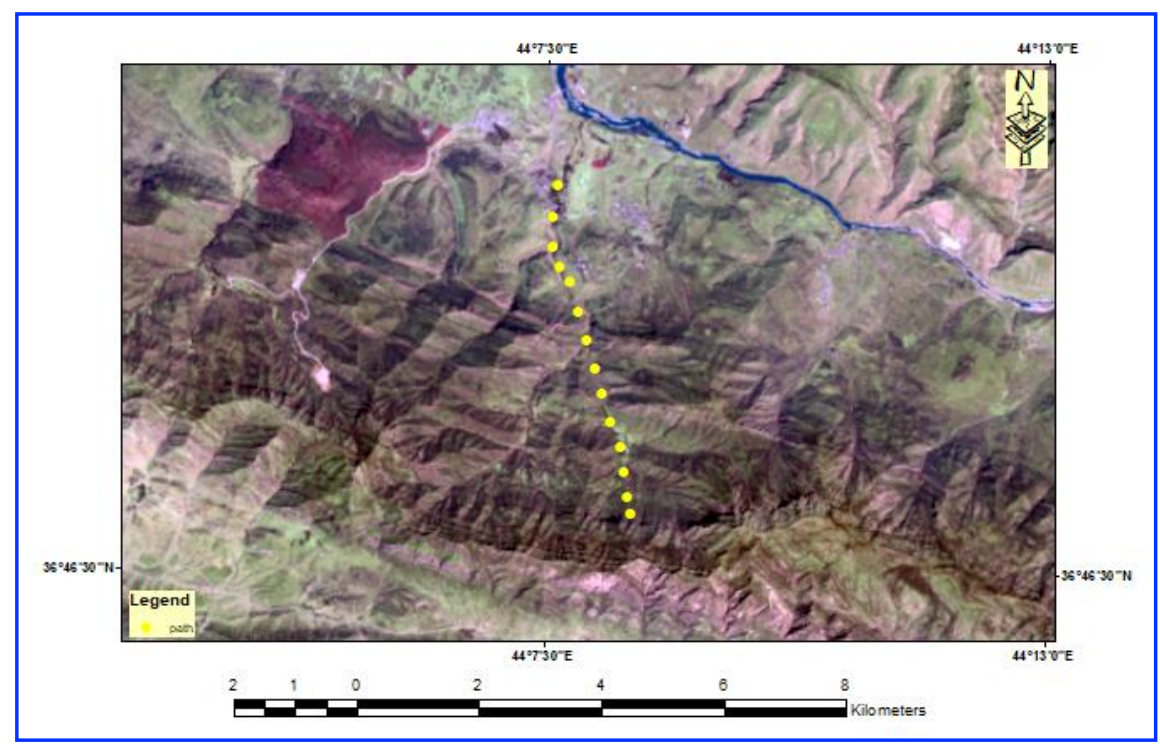

Fig. 10. The dashed yellow line shows the path location of the detailed survey

\subsection{Undulating Index}

The authors derived an equation of undulating index UI to extract the undulating value of the anticline. This adaptive equation can be ready to apply for all other undulating anticlines. The undulating index was determined by the difference between a mountain and plain slopes (Fig. 7). The length of the anticline ( $\mathrm{L}$ ) is defined by the displacement between two extreme plunge points. The maximum displacement between $\mathrm{L}$ and the anticlinal front wave peak is defined as $\left(\mathrm{W}_{1,2,3 . \mathrm{n}}\right)$ on both sides of $\mathrm{L}$. Consequently, the undulating index is calculated as:

$$
U I=\frac{W}{L} * 100
$$

The summation of the undulating indices on each side refers to the direction and magnitude of the tectonic force (Fig. 11). Most researchers measure the relation between tectonics and erosion by the mountain-front sinuosity $\left(\mathrm{S}_{\mathrm{mf}}\right)$ (Khalifa, et al., 2018; Azor et al., 2002). This index describes the ratio of the lengths of the mountain front to the straight line approaching the more active tectonic setting. The mountain front sinuosity has considered a morphological index, while the undulating index has considered a tectonic index because the $S_{\mathrm{mf}}$ has been affected by erosion, whereas the UI by the tectonic activity. The greater UI refers to the direction of the tectonic force. The smaller and greater differences between UI of each limb refer to the low and high tectonic force magnitude respectively. Since the strike-slip faults are right-slide left-order (dextral) (Fig. 11) or left-slide right-order (sinistral), the fold is subjected to compression, therefore, decreases the anticline width (Fig. 12) (Yin, et al. 2018). Listric fault reactivation, deformation of thin skin, and large anticlines which are related to the deformation propagation have been caused by the collision of plates and rotation (Sadeghi and Yassaghi, 2016). The cause of undulation in the fold is due to the effect of the movement of the Arabian plate towards the northeast, and its rotation counterclockwise (Omer, 2005). Furthermore, the effect of the relative movement of the strike-slip faults resulting from the presence of listric faults in some parts of the fold led to reducing the undulating (Fig. 11). It is also noted in the fold that the relaxation of stress on listric faults led to a decrease in the rate of undulating (Fig. 11). In this context, dwindling in the tectonic effect in those areas has caused a decrease in height relative to vicinity areas that are not affected by the faults (Fig. 5). 


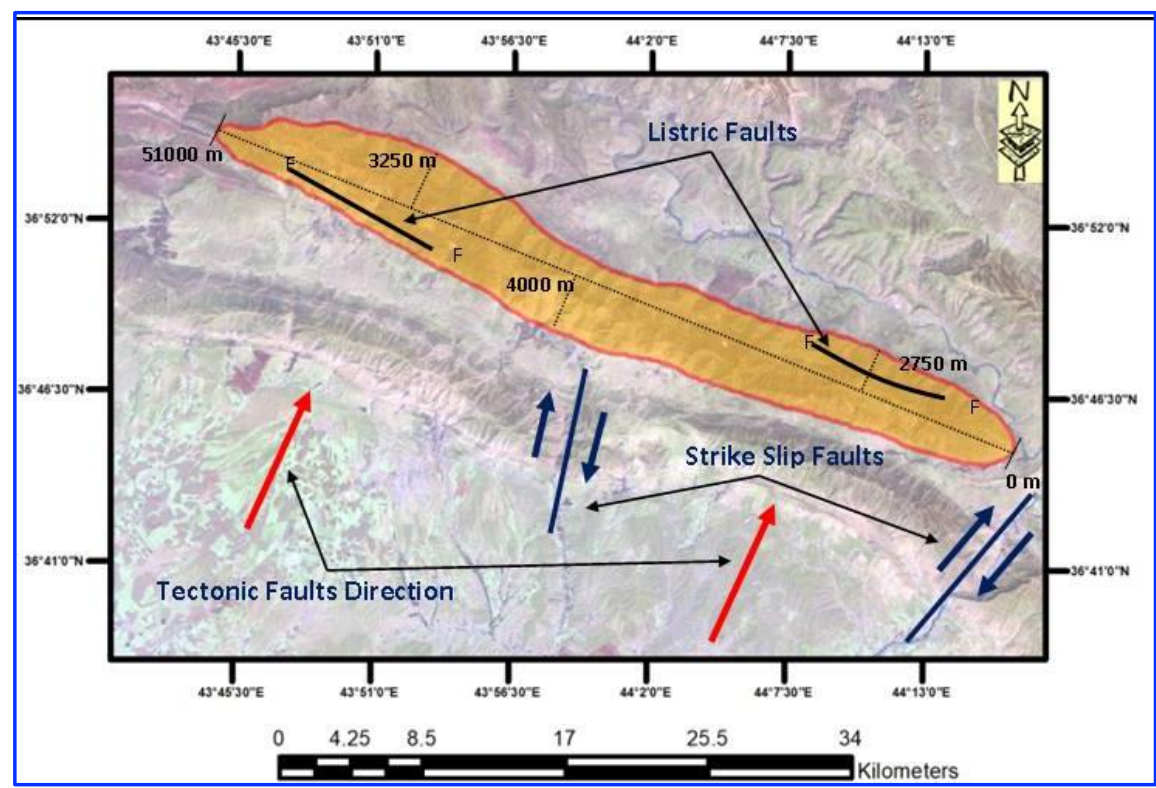

Fig. 11. A sketch diagram illustrates the direction of the tectonic forces from analyzing the undulating index

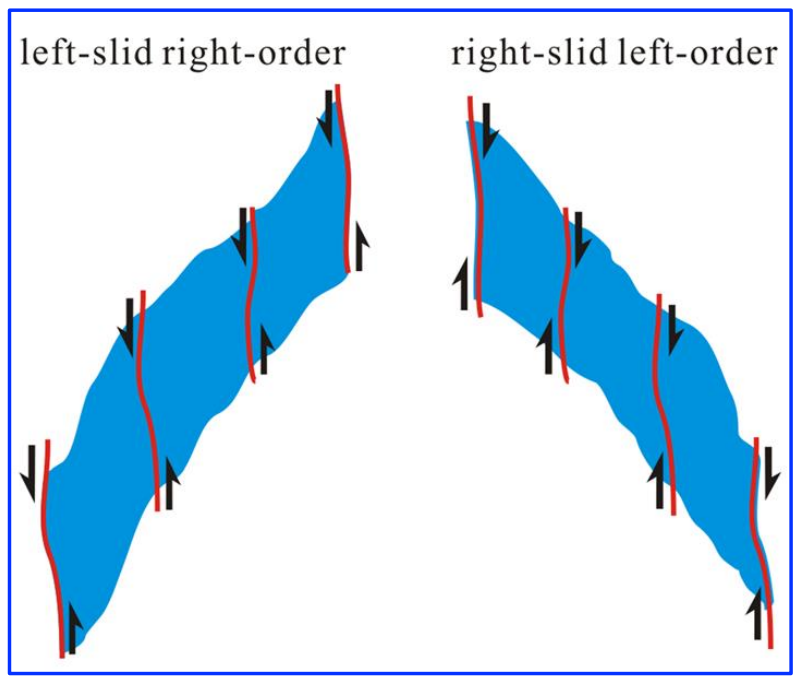

Fig. 12. The explanation of the movements of compressional environments for faults (Yin et al. 2018)

\section{Results and Discussion}

In Chinara anticline, multiple morphotectonic features were concluded by analyzing the digital elevation models with four terrain models, field investigations, and derived undulating equation as follows:

\subsection{Fault Escarpment}

The contour map showed a clear deviation in lines in certain specific anticline areas (Fig. 4). It reveals the presence of severe erosion of the valleys due to the shear structures concentrated in this area (Fig. 6C) or to the listric faults of the northeastern limb parallel to the fold-axis (Fig. 6D and Fig. 12). The influence of listric faults has led to folds' growth in the most north and northeast of Iraq (Numan, 1997; Numan, 2000; Numan, 2001; Omer, 2005; Numan and Azzawi, 1993). These faults have been activated due to the collision of the Arabian plate with Iranian and Turkish plates. A geological model was established in this study of these faults that affect the northern limb of the anticline (Fig. 14). 


\subsection{Tectonic Uplift}

Two regions of the tectonic uplift are located in the anticline (Fig. 5). The first was 1533 meters and the second was 1722 meters in the southeastern and northeastern plunges respectively. The appearance of these tectonic uplifts might indicate that it has not been affected by the branched listric normal fault. It contributes to making a middle part of the anticline more eroded, because of restrictedly extending in this part of the anticline (Fig. 13).

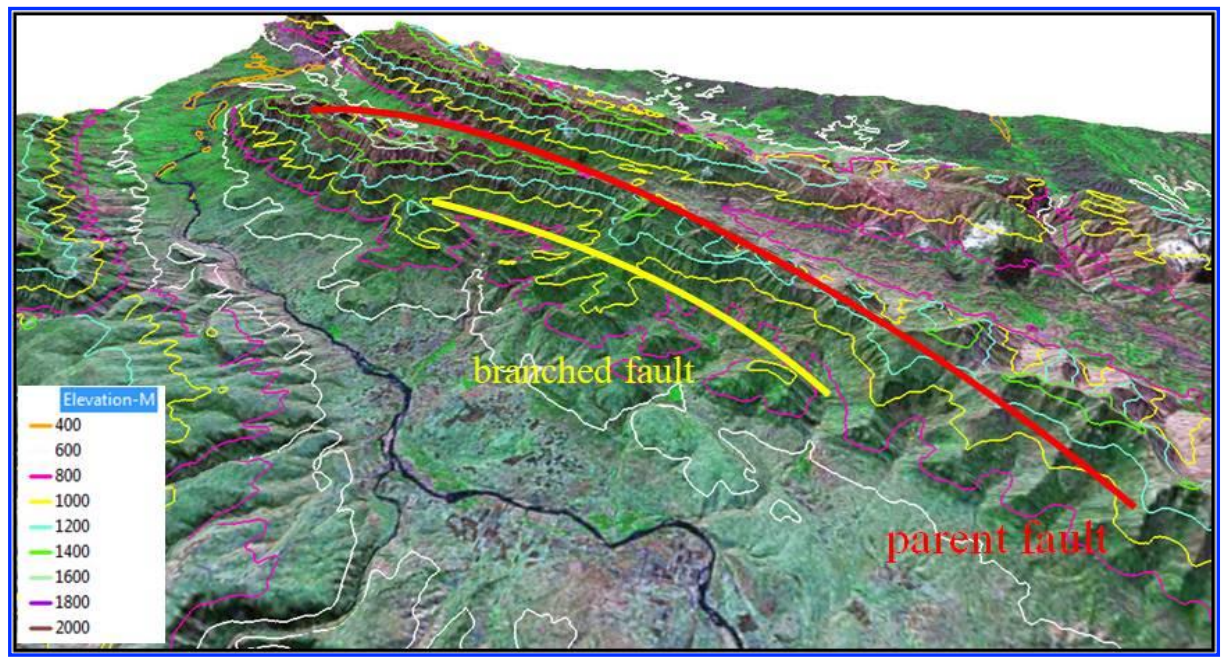

Fig. 13. The 3D model shows the approximate locations of the branched and parent listric faults

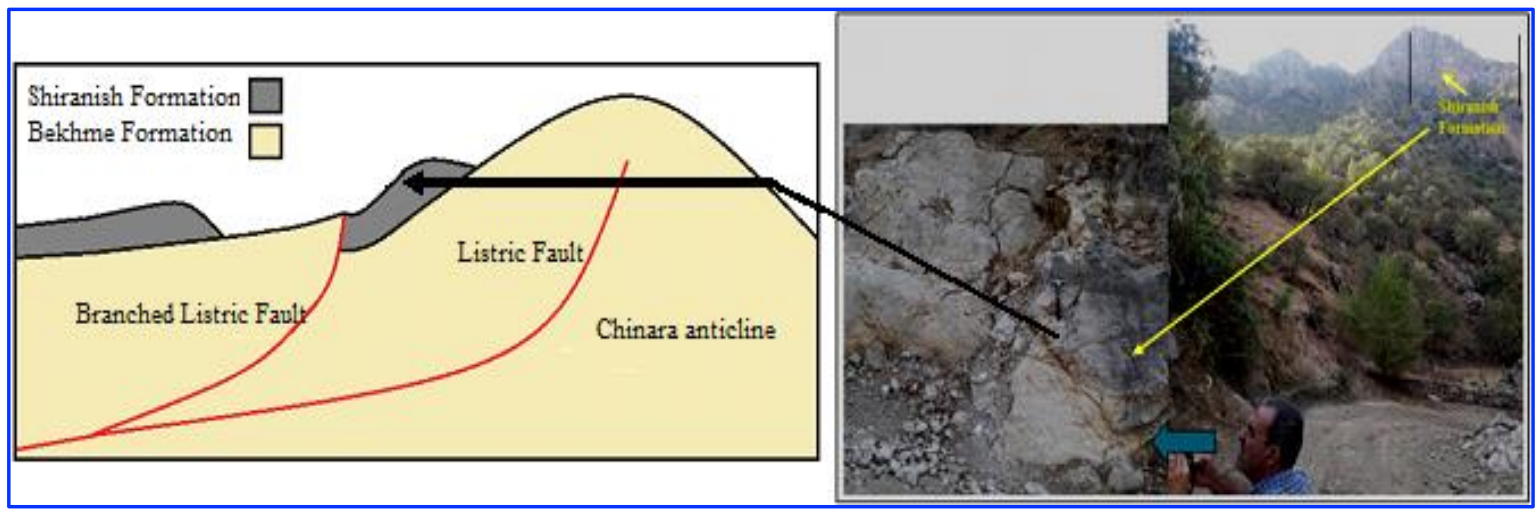

Fig. 14. The virtual model illustrates the branch of the listric fault affecting the Shiranish Formation

\subsection{Undulating Axis}

The undulating axis has been observed along with the two limbs of the Chinara anticline (Fig. 11). The northeastern limb was more relatively undulated than the southwestern limb (Fig. 11). To interpret this phenomenon, the UI equation was created to calculate the undulating on both limbs of the anticline, which revealed that the northeastern limb has more undulated than the southwestern limb as a result of the separation of break of slope (Fig. 5). The northeastern limb undulating index according to the UI equation is 11.7, while the southwestern limb is 7.8, indicating the intensive tectonic force from the northeastward (Fig. 11). This equation is considered as a principal to clarify all the undulating forms in the High Folded Zone of Iraq. On the other hand, the outcrops and their sudden interruptions, on some parts of the northeastern limb are related to the broad syncline between the northeastern limb of the Chinara anticline and the southwestern limb of Bradost anticline. On the contrary, there are no outcrops observed on the syncline extended between the southwestern limb of Chinara anticline and the northeastern limb of Aqra and Perat anticlines because these folds are close together, i.e. Chinara and Perat anticlines (Fig. 5). 


\subsection{Morphotectonic Features}

The 3D model (Fig. 8) refers to the tectonic uplift of part of the obvious syncline extended near the northwestern plunge of the Chinara anticline. The axis of syncline, which disappeared within the Greater Zap River along the northeastern limb of the Chinara anticline, has accompanied the anticline tectonic uplift, specifically in the northwestern plunges of the three anticlines. The reconnaissance field survey explained the structural location of Chinara anticline according to the Perat and Bradost anticlines which plunged into the syncline between these two anticlines (Fig. 15). Drainage patterns are ambiguous at the northeastern limb of the Chinara anticline; abundant drainage valleys, straight and narrow around the anticline, except the definitive part near Darbotic and Alka villages that are defined by huge two valleys, which trend NS and SE-NW (Fig. 9). The climate and structural geology have influenced the development of the landform (Fatah, et al., 2020).

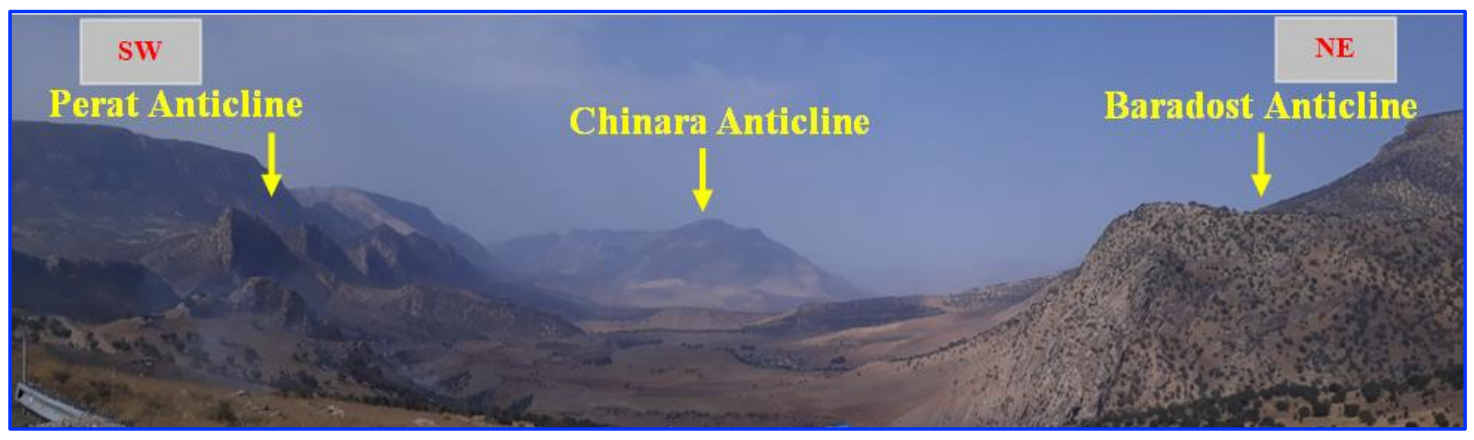

Fig. 15. Structural location of the Chinara Anticline between the Perat and Bradost anticlines

A detailed survey was made from Darbotic Village towards the area near the core of the anticline that observed the change in bedding dip from $5^{\circ}$ to nearly vertical. The distance of the survey line about $6.25 \mathrm{~km}$. (Fig 10). The expecting breakthrough at the end of the survey line is exposing the Shiranish Formation between the beds of the Bekhme Formation (Fig. 14). Outcropped repetition of the Shiranish Formation might be related to the impact of reverse fault that branched into two parts. The first one formed the fold, and the second led to arise the outcrop of the Shiranish Formation within the beds of the Bekhme Formation. The other significant morphotectonic feature is the spring water. Through the fieldwork, the authors documented the presence of spring charging the water to five villages; started from the area near the Shiranish Formation exposures, and flow about several meters in the valley and then sinking to the ground.

\section{Conclusions}

The integration between fieldwork, morphotectonic features, and 3D terrain provides much information that is significant to conclude the tectonic and structural setting of the Chinara anticline and suburbs area. The northeastern limb of the anticline has seen different distributions in the drainage patterns. There are several, straight and narrow drainage valleys along the anticline while there is only underling huge two wide valleys between Alka and Darbotic villages. The variety of drainage patterns in the northeastern limb of the anticline is attributed to the structural impact of the tectonic growth. The effect of the listric reverse fault causes the Shiranish Formation repetition and be exposed by branching into two faults. Listric faults absorb the compressive tectonic stress caused by the plate movement and thus reduce the undulation of the anticline axes. If strike-slip faults had more impact than those of listric faults, then the Chinara anticline would be undulated in a region of enclosed syncline similar to Perat undulating. The derived equation for calculating the undulating index verified the tectonic impact direction and the influence of strike-slip and listric faults. 


\section{Acknowledgements}

The authors would like to express gratitude to Mosul University, Mosul, Iraq for their support to complete this work. For much fruitful cooperation on field trips, we thank our colleague Tarik Khalid manager of the Soran Irrigation Directorate, Kurdistan Region, Iraq. The authors are very grateful to the Editor in Chief Prof. Dr. Salih M. Awadh, the Secretary of Journal Mr. Samir R. Hijab. and the Technical Editors for their great efforts and valuable comments.

\section{References}

AL-Hamdani, R. K.. 1991. Stratigraphy and Structure of the Southeastern Part of Perat Anticline (Bekhme Area). The University Of Mosul.

Al-Sulttani, A .H, Ayad, A. B., 2020. Hypsometric analysis of Al-Adhaim Basin using a new GIS technique. Iraqi Geological Journal, 154-70.

Anand, A. K., Prasad, P. S. and Kumar, K. 2017. Geomorphometric analysis of Chamoli and Karnaprayag District, uttrakhand in respect to hazard zonation of the area. Journal of Remote Sensing and GIS, 6 (2), 6-11.

Azor, A., Edward, A. K., and Robert, S. Y. 2002. Geomorphic indicators of active fold growth: south mountainOak Ridge Anticline, Ventura Basin, southern California. Geological Society of America Bulletin, 114 (6), 745-53.

Choanji, T., 2016. Slope analysis based on SRTM digital elevation model data: study case on rokan iv koto area and surrounding. Journal of Dynamics, 1 (2).

Fatah, K. K., Shwan, S., Shvan, J., 2020. Morphometric analysis using geo-information techniques for different watersheds in northeastern part of Erbil City, Kurdistan Region, North Iraq. Iraqi Geological Journal, 88104.

Hessami, K. H, and Jamali, F., 2006. Explanatory notes to the map of major active faults of Iran. Journal of Seismology and Earthquake Engineering, 8 (1), 1-11.

Jackson, J. A., Fitch, T.J., McKenzie, D.P., 1981. Active thrusting and the evolution of the Zagros Fold Belt.” Geological Society, London, Special Publications, 9 (1), 371-79.

Jassim, S. Z., Goff, J. C. 2006. Geology of Iraq. Edited by Lea Novotna. 1 st. Dolin, Hlavni 2732, Prague and Moravian Museum, Zelny trh 6, Brno, Czech Republic.

Kettunen, P., Christian, K., and Juha, O.. 2017. A design of contour generation for topographic maps with adaptive DEM smoothing. International Journal of Cartography, 3 (1), 19-30.

Khalifa, A., Ziyadin, C., Lewis, A. Owen, ŞİNASİ, K. 2018. Morphotectonic analysis of the East Anatolian Fault, Turkey. Turkish Journal of Earth Sciences, 27 (2), 110-26.

Konon, A., Michał, S., 2006. DEM-based structural mapping: examples from the holy cross mountains and the outer carpathians, Poland." Acta Geologica Polonica 56 (1): 1-16.

Mitas, Lubos, and Helena Mitasova. 1999. Spatial interpolation. Geographical information systems: principles, techniques, management, and applications, 1 (2).

Mukul, M., Vinee, S., Sridevi, J., Malay, M.. 2017. Uncertainties in the Shuttle Radar Topography Mission (SRTM) Heights: Insights from the Indian Himalaya and Peninsula.” Scientific Reports 7: 41672.

Numan, N. M. S., 2000. Major Cretaceous tectonic events in Iraq. Rafidain Journal of Science, 11 (3), 32-54.

Numan, N. M S., 1997. A plate tectonic scenario for the Phanerozoic Succession in Iraq.Iraqi Geological Journal, 30 (2), 85-110.

Numan, N., M. Nabil, A., 1993. Structural and geotectonic interpretation of Vergence Directions of anticlines in the foreland folds of Iraq.

Numan, N. M. S., 2001. Cretaceous and Tertiary Alpine subductional history in Northern Iraq." Iraqi Journal of Earth Science, 1 (2), 59-74.

Omer, A. A., 2005. An Integrated Structural and Tectonic Study of the BinaBawi-Safin-Bradost Region in Iraqi Kurdistan.” Unpublished Ph. D. Thesis, Department of Geology, Salahaddin University, Erbil.

Onur, T., Rengin, G., Abdulnaby, W., Mahdi, H., Numan, N. M. S.,Al-Shukri, H., Shakir, A. M., Chlaib, H. K., Ameen, T. H., Abd, N., 2017. A comprehensive earthquake catalog for Iraq in terms of moment magnitude. Seismological Research Letters, 88 (3), 798-811.

Ripley, B. D., 2005. Spatial Statistics. Vol. 575. John Wiley \& Sons. 
Robinson, A. H., 1971. The genealogy of the isopleth.Cartographic Journal, 8 (1), 49-53.

Sadeghi, S., Yassaghi, A., 2016. Spatial evolution of Zagros Collision Zone in Kurdistan, NW Iran: Constraints on Arabia-Eurasia Oblique convergence. Solid Earth, 7 (2), 659.

Sissakian, V. K., Ibrahim, E. I., Al-Waíly, I. J., 1997. Geological map of Arbeel and Mahabad Quadrangles sheets NJ-38-14 and NJ-38-15. Scale 1: 250.

Sissakian, V. K., 2013. Geomorphology and morphometry of the Greater Zab River Basin, North of Iraq. Iraqi Bulletin of Geology and Mining, 9 (3), 21-49.

Szypuła, B., 2017. Digital elevation models in geomorphology, hydro-geomorphology-models and trends. InTech Open, 81-112.

Thornton, J. M., Gregoire, M., and Philip, B., 2018. A 3D geological model of a structurally complex Alpine Region as a basis for interdisciplinary research. Scientific Data , 5 (1), 1-20.

Yin, S., Dawei, L.V, Zhonghu, Wu, Wenlong, D., 2018. Assemblage of strike-slip faults and tectonic extension and compression analysis: a case study of a lower permian commercial coal reservoir in China. Journal of Earth System Science, 127 (6), 77.

Zuidam, R. Antonius, V., 1979. "Terrain Analysis and Classification Using Aerial Photographs: A Geomorphological Approach, ITC Text Book of Photo Interpretation, 1, Enschede. 